Prithvi N. Shrestha*

\title{
Designing an online business communication course in English by responding to student needs through an evidence-based approach
}

Abstract: Communication skills are essential for the employability and academic success of business graduates. These skills are either embedded in undergraduate business management courses or taught in a separate course. Designing an English communication course for business management students is reported widely in the literature. However, research on such courses for distance education is scarce despite their increasing demand for distance courses due to an increasing globalisation of higher education and workplaces. This paper reports on the evidence-based design of an award-winning online business communication course in English which responded to changing needs of distance business management students at The Open University, UK. It draws on student needs analysis data (student surveys, online forum posts, industry skills survey reports and a content analysis of business management courses and assignments) and course evaluation surveys to investigate how the online course addressed student needs in terms of course content, teaching and learning and assessment. It argues that student needs analysis is paramount for any new course design and online delivery because the success of a course relies on meeting student needs. The paper has implications for business communication course design and business communication teachers.

Keywords: assessment strategy; business communication in English; course design; evidence-based approach; needs analysis; open and distance education

\section{Introduction}

Communication skills are one of the key attributes required of employees in any workplace. For example, a recent skills survey by the Confederation of British

\footnotetext{
*Corresponding author: Prithvi N. Shrestha, School of Languages and Applied Linguistics, The Open University, Milton Keynes, UK, E-mail: prithvi.shrestha@open.ac.uk 
Industry (CBI) showed that employers expect their prospective employees to have solid oral and written communication skills (CBI, 2015). This means all graduates including business graduates need to acquire these skills in their university study programmes (e.g., see Clokie \& Fourie, 2016). In particular, oral communication skills compared to written communication skills seem to be lacking in business graduates due to the narrow focus within business management programmes on oral presentations only (Crosling \& Ward, 2002; Jackson, 2014). Although this situation was reported in the context of face-to-face management education, this applies even more to distance education (the context of this paper) given the primacy of literacy (i.e., communication and subject knowledge primarily in written mode) and the challenge of providing opportunities for oral communication to distance students (Shrestha, Fayram, \& Demouy, 2015).

This paper is concerned with needs of distance education students at The Open University (OU), UK and thus it is important to explain the nature of these students. They are considerably different from those in other universities for a number of reasons: they are almost all part-time students and most of them may be in fulltime employment; students are isolated and dispersed across the country and globally rather than being in a campus. Most of these students use English as their first language although they may need support with using academic English or English in business communication. Unlike in traditional universities, there is no distinction between 'home' and international students and thus students are not treated differently due to their linguistic backgrounds. The institutional assumption is that all students benefit from support with academic and professional communication. In addition, unlike those in traditional universities, most students are mature and over 30 years old (some students being over 70) although increasingly younger students (e.g., under 18s) are studying with the OU. The other distinguishing factor is OU's no entry requirement for first year (Level 1) undergraduate courses, as part of its social justice agenda and mission ('open to people, places, methods and ideas'). As distance learning students tend to be already in employment, they will have deeper insights into workplace realities and demands. Thus, understanding their needs compared to traditional university students provides richer data to a needs analysis. Additionally, how course material is presented to students in distance learning is pertinent because the material cannot be changed as quickly as in face-to-face teaching. Therefore, understanding student needs for the course material format or structure is key to the course's success. Keeping all this in view, this paper reports on a successful design of an online business communication course in English (BCCE) at the OU, UK to meet student needs through an evidence-based approach which draws on multiple sources of needs analysis data. 
This paper contributes to the growing body of research on designing a business communication course in English (BCCE) which entails considering key concepts and frameworks in business management, business communication and use of English language. This means business language learning is only a part of the course design. The paper first reviews the relevant literature by focusing on studies related to business communication course content, student needs analysis and course design approaches which are pertinent to making an online BCCE to meet changing student needs. This will be followed by a description of the methodology used to collect and interpret data. Next, key findings on course content, student needs, teaching and learning including course delivery and assessment, and their applications to the design of the new BCCE are reported. The findings are then discussed in the light of the existing literature followed by implications for business communication course design and business communication teachers.

\section{Literature review}

Today's workplace or professional setting is characterised by multilingualism although there is usually a dominant language such as English, dependent on the location. Whether it is a multilingual or "monolingual" workplace setting, communication plays a pivotal role in activities such as negotiating at business meetings, establishing one's identity and carrying out workplace tasks effectively. This has been highlighted by research on workplace discourse and cultures (e.g., see Angouri, 2018). Business management students need opportunities to learn various aspects of business communication in their degree programmes so that they can be prepared for both their academic study and professional journey. Therefore, it is essential for us as educators to ensure that we provide opportunities to our business management students to enhance their communication skills through our courses. There is a burgeoning body of literature on business communication. For the purpose of this paper, I will focus on studies related to business communication in three areas which are central to the course design: course content, student needs analysis and course design approaches. Course design in this paper refers to the combination of activities from surveying student needs, designing the course syllabus, writing teaching and learning materials, producing audio-video materials to creating assessment tasks. It should be noted that there are a number of publications focused on online second language learning/ teaching and course designs (e.g., Colpaert, 2006; Hampel \& Stickler, 2015; White, 2017). However, they focus on general second language learning which is not the focus of this paper and thus are not reviewed here. Instead, key studies which 
exclusively focus on business communication and English for business communication are reviewed.

\subsection{Course content}

One obvious aspect of any course design is the choice of content. The content of a BCCE is influenced by a number of factors such as employers' needs, changes in the discipline and changing landscape of the workplace or profession as reported in the literature (Bhatia \& Bremner, 2012; Moshiri \& Cardon, 2020; Wardrope \& Bayless, 1999). As a result of these changes in both academic and professional contexts, BCCE continues to evolve globally (Bargiela-Chiappini \& Zhang, 2013) due to the dominance of the English language in the business world where it serves as a lingua franca (Neeley, 2012). This means the content of a BCCE is inevitably influenced by how people use the English language in the business world (i.e., business English discourse) to get things done.

Broadly, a business communication course consists of both oral (e.g., individual presentation and discussions) and written (e.g., reports) communication components although the emphasis on one or the other has changed over the years as shown by a recent business communication course audit in the US (Moshiri \& Cardon, 2020). While earlier courses tended to have content based on idealistic notions of business English and student needs, as argued by Bargiela-Chiappini and Zhang (2013), the most recent courses appear to draw on empirical research such as business discourse analysis conducted in organisations or workplaces. There are also many business English textbooks published by multinational publishers such as Pearson. However, these textbooks have often been criticised for the discrepancy between the authentic English business discourse found in business organisations and what is included in these textbooks (Bargiela-Chiappini, Nickerson, \& Planken, 2007; Bargiela-Chiappini \& Zhang, 2013; Bhatia \& Bremner, 2012) although a limited number of corpus-informed Business English textbooks have been developed more recently.

The coverage of the actual business communication content has been researched by auditing available courses. These audit studies were primarily in the US in the last 50 years (Moshiri \& Cardon, 2020; Wardrope \& Bayless, 1999) and there seems to be no such detailed auditing elsewhere. According to these audits, the earlier BCCEs predominantly covered business writing such as reports and memos and gradually they started including oral presentations. Team communication or collaboration was sparsely taught. However, recent two national audit studies (Moshiri \& Cardon, 2014, 2020), probably the most comprehensive to date, indicate that BCCEs in the US continue to cover business writing or written 
communication principally, followed by (oral) business presentations, teamwork or team communication, public speaking and interpersonal communication. According to Moshiri and Cardon (2014, p. 318), the most common types of written communication content included the following (presented in the order of highest to lowest coverage): Persuasive messages, Routine (or positive) messages, Cover letters and/or résumés, Bad-news (or negative) messages, Business proposals, Secondary research papers, Primary research papers, Public relations messages, Crisis messages and Business plans. Their updated 2020 study indicates that the BCCE content coverage has changed positively according to the authors as they include additional topics reflecting new developments in the business world: Organizational Communication, Corporate Communication, Handling Q\&A, Ethics, Intercultural communication, Research papers, Corporate Social Responsibility, Diversity, Online presentations, Social media/Internet communication and Proposal and grant writing (Moshiri \& Cardon, 2020, p. 3). Moshiri and Cardon (2020) also report BCCEs emphasising critical thinking and problem-solving. However, they indicate that existing BCCEs lacked topics on online or digital communication and the role of language in communication which is surprising. Likewise, there was also no mention of negotiations, a topic that is widely researched in business discourse studies (Bargiela-Chiappini et al., 2007; Bargiela-Chiappini \& Zhang, 2013; Bhatia \& Bremner, 2012; Koester, 2006).

The field of business communication in English is significantly influenced by business communication studies because the combination of English for business purposes and business communication studies appears to offer a better coverage of authentic business communication (Bhatia \& Bremner, 2012) given their similar goals. Therefore, Bhatia and Bremner (2012) call for BCCEs to include aspects from both areas because language (such as English) is used to make meanings in a management education or business context and real business communication provides contexts for the English language to be meaningful and authentic, thereby preparing students for their real future workplace needs.

Despite the continuously evolving nature of BCCEs, they do not yet reflect the significant impact of local and global business cultures on business communication and the increased use of virtual communication. More importantly, the existing literature has little information about the nature of a BCCE for distance education.

\subsection{Student needs analysis}

Course content in BCCEs is determined by target students' needs. Therefore, needs analysis has been a key aspect of a BCCE and it has been researched quite 
extensively in the field of English for specific purposes (ESP) (Basturkmen, 2010; Bhatia \& Bremner, 2012; Flowerdew, 2013; Hellekjær \& Fairway, 2015; Johns, 2013). Needs analysis refers to identifying the what and how of a course design. In the context of a BCCE, the what broadly entails the kind of English language and business communication skills needed in different business communication scenarios (e.g., writing a report on employees' health and safety needs in the pandemic for senior managers, meetings) that students encounter. The how refers to the pedagogy used to deliver the course content. Needs analysis should also take into account students' current knowledge, backgrounds and learning preferences. As this needs analysis process is dynamic, student needs are regularly examined to update the course. As such, in a review of needs analysis, Flowerdew (2013) states that the methods for needs analysis include, among others, expert intuition, participant observations, consultations with business academics, student surveys, workplace observations and genre analysis including corpus-based analysis.

The literature on student needs analysis is primarily related to ESP rather than business communication. As it is relevant, some key aspects are discussed here. The ESP literature shows that needs analysis may be driven by what students need in a target business communication context (target situation analysis) and what they lack or want (present situation analysis) (Flowerdew, 2013). While the early needs analysis focused on teacher intuition, later needs analysis approaches gather data from multiple sources including students and various contextual sources such as business communication in actual workplaces and business discourse corpora (Bhatia \& Bremner, 2012; Koester, 2010).

One of the key needs analysis methods in ESP appears to be genre (text type) analysis whether in academic or professional contexts, especially influenced by the works of Swales in the academic context (e.g., Swales, 1990) and Bhatia in the professional context (e.g., Bhatia, 1993, 2004) (for an extended review of genre approaches see Bawarshi \& Reiff, 2010). Genre is seen as a socially situated action with a shared communicative purpose. Various key text types from academic and professional contexts are analysed for their rhetorical moves (discourse structure) and lexicogrammar which writers use to achieve the social purpose of a text. These features are made 'visible' and taught in ESP courses. Conventionally, genre analysis focuses on texts. However, more recently the needs analysis in academic writing has been influenced by ethnographically-oriented academic literacies (Lea \& Street, 1998; Lillis, 2001; Turner, 2011) and critical English for academic purposes (EAP) (Benesch, 2009). This means analysing wider institutional contexts and ideologies surrounding the text in question. Adopting this kind of needs analysis comes with challenges such as time and resource constraints and therefore, course designers may tend to focus on target texts only. It is worth noting that the ESP genre analysis has focused on needs of postgraduate international students rather 
than the general student population (as in this paper) in English medium higher education.

In addition to the ESP approach, Systemic Functional Linguistics (SFL) pioneered by Halliday $(1993,1994)$ has influenced genre analysis to support disadvantaged learners (i.e., those who come from "working class" and low socio-economic backgrounds and may not have access to academic discourse unlike students from rich and middle class families) in schools and higher education through the works of SFL genre theorist Jim Martin and colleagues (e.g., Coffin \& Donohue, 2014; Martin, 2009; Martin \& Rose, 2007; WoodwardKron, 2005). As SFL-informed the course design examined in this paper, it needs further explanation.

From an SFL perspective, language is viewed as a resource for making meaning in a particular social context. This means language helps to realise a social context through the choice of language used. In the SFL-based genre theory, genre is defined as "a staged, goal-oriented social process. Social because we participate in genres with other people; goal-oriented because we use genres to reach our goals" (Martin \& Rose, 2007, p. 8). As Coffin and Donohue (2012, p. 66) explain, SFL-based genre theory draws on the concepts of register and genre in analysing academic texts, especially to describe and account for how language operates in academic contexts. While the notion of genre is used to map texts in a discipline according to their key purposes (e.g., arguing, describing, recounting etc.), register variables ( field - subject matter, tenor - reader-writer relationship and mode - medium of communication) are deployed to understand the relationship between the sociocultural context of written or spoken texts and the lexicogrammatical choices in a text. The SFL genre analysis is also influenced by academic literacies in recent years as can be seen in some works in higher education which examine contexts beyond text through an ethnographic-oriented approach (e.g., Coffin \& Donohue, 2014; Shrestha, 2020).

In most recent research on BCCE students' needs, two additional aspects have been identified as essential for a course. They are oral business communication and intercultural or cross-cultural communication. A number of studies emphasise that a BCCE should include oral business communication beyond the oral presentation (e.g., "small talk", daily routines) to enhance students' employability (Cavanagh, Leeds, \& Peters, 2019; Clokie \& Fourie, 2016). Likewise, some studies strongly suggest the need for teaching business communication students cross-cultural communication which involves learning ways of communicating with people from different cultural and ethnic backgrounds (Angouri, 2018; Smallwood, 2020). 


\subsection{Course design approaches}

A course design approach in this paper refers to the pedagogical decisions regarding the course including assessment. The body of existing ESP literature suggests that pedagogical practises are changing according to the context, purpose, student needs, available pedagogic support resources and assessment (Paltridge \& Starfield, 2013). The needs analysis informs what kind of pedagogical approaches need to be adopted in the course which may subsequently determine any pedagogy and assessment. For example, as discussed in Section 2.2, genre analysis has been dominant in needs analysis and thus genre-based pedagogies have been influential in ESP teaching and learning too, especially in EAP and academic writing (Hyland, 2007; Wingate, 2018). The genre pedagogy typically adopts a task-based learning approach and focuses on different aspects of a target genre (e.g., a workplace proposal) such as its discourse moves and the type of lexicogrammatical resources required to produce it. It also makes learners aware of the context where the genre is used instead of just looking at the text product. In genre-based pedagogies, the kind of discourse moves and the required language use are explicitly taught to students so that they can acquire the target genre (Hyland, 2003; Paltridge, 2013). In addition to genre acquisition, some scholars suggest that genre-based pedagogies should raise students' genre awareness by providing them with strategies to respond to new genre tasks and situations (Cheng, 2007; Johns, 2008). The ESP-oriented genre pedagogy does not seem to advocate any particular pedagogical approach.

The SFL-based genre pedagogy, however, has a clearly defined pedagogical approach originally called the Teaching and Learning Cycle (TLC) in the 1980s (for details on its development, see Rose \& Martin, 2012). This pedagogy was developed to explicitly teach school children how to write the identified genres in a particular school year. The pedagogical approach was mainly based on Halliday's and Painter's SFL-based language development studies (Rose \& Martin, 2012). Only later (i.e., turn of the century and early 2000) was Vygotsky's notion of "zone of proximal development" (ZPD, i.e., learning potential) brought into the development of SFL-based pedagogy which emphasises dialogue in teaching and learning (e.g., Gibbons, 2002, 2006; Hasan, 2005a, 2005b; Martin, 1999). Viewing it as a genre, this pedagogical approach (i.e., TLC) has three distinct stages: Deconstruction, Joint Construction and Independent Construction. At the Deconstruction stage, the teacher introduces a model text of the target genre and discusses its sociocultural context, generic stages and lexicogrammatical features. The Joint Construction stage involves the teacher and their students jointly constructing (writing) another text in the same genre in the classroom (or online). The final stage, Independent Construction 
requires students writing a text in the same genre on their own (e.g., at home). In all these three stages, building the field and setting the context are central. The key purpose of the approach is to enable students to take control of the target genre so that they can write it and critically reflect on its role.

Assessment needs to be central to any course design and its pedagogy. One may argue that assessment in BCCE is the same as in other language assessment. However, due to the specific nature of language use and communication contexts, the construct we assess can be very complex and challenging, and what assessment criteria we use to assess BCCE students may be debatable as contended by Douglas (2013) in the context of ESP. Yet, it can be argued that the construct to be assessed and the criteria need to be derived from the business communication course context.

In addition to genres and their contexts, as argued by Flowerdew (2013), pedagogical decisions need to consider the use of educational technologies and globalisation in BCCE, especially for distance education. As an emerging area of research, there is only a limited amount of research on the use of technologies in BCCE (though see White, 2017 for online second language learning) but some studies show the positive impact mobile learning has on student learning (e.g., see Knight, 2017). Globalisation is relevant to this paper as distance education students come from around the world and they bring different identities and profiles as a learner which affects the course design. However, both technologies and globalisation are under-researched in the context of BCCEs.

\section{Research questions}

Given the lack of research on BCCE in distance education as shown in the literature review, there is a need for building our knowledge further in this area. For this reason, the following two research questions have been addressed in this paper:

- What are distance undergraduate business management students' communication needs?

- In what ways does an evidence-based course design address such needs?

\section{Material and methods}

\subsection{Research context}

Learning and teaching in open and distance education (The OU in this case) is significantly different from traditional universities (Chetwynd \& Dobbyn, 2011). 
Therefore, it is essential to understand how teaching and learning takes place in such a context. Unlike in other universities, students in the OU have limited or no face-to-face contact with their teacher or their fellow students during the course of their studies because face-to-face tutorials are provided in a limited number. Online tutorials are increasingly becoming the norm in most of the OU courses. In terms of the study materials, all undergraduate courses provide all materials online even when there is also a printed book. While some courses continue to provide students with printed books, many courses now offer only limited materials in print and most of the materials online on a dedicated course website. The OU courses run for 6-9 months each year. Each course has its own course team that consists of academic (a course chair and two or more other academics), administrative and production (i.e., editor, online support) staff. Designing and running a course always involves collaborative teamwork across different units in the OU. Each course has a number of tutors depending on the number of students enrolled. An OU tutor, officially called Associate Lecturer, has 16 to 20 students in their group for tutorials and assessment marking. The tutor has contact with students via a private online forum called Tutor Group Forum within the course website, custom-built on the Moodle platform. This online forum is used to build a community and for students to carry out learning activities in small groups. The tutor also uses email and telephone to contact their students. For tutorials, each tutor uses an online room (currently Adobe Connect ${ }^{\circledR}$ ) at different points in the course; this offers students and their tutor opportunities to discuss anything related to the course in real-time.

Assessment in the OU is primarily conducted through the written mode except in Languages courses. Each course contains 2-6 Tutor Marked Assignments (TMAs). TMAs spread across the course and each TMA assesses a certain topic area. The TMA is designed not only to assess what students have learned in the course but also provide formative feedback that students can use in their subsequent assignments (TMAs) (Chetwynd \& Dobbyn, 2011).

The data reported in this paper comes from an undergraduate business communication course in English (UBCCE) for business management at The OU Business School (OUBS). UBCCE is a 30 credit point ( $300 \mathrm{~h}$ ) optional course offered to all undergraduate OUBS students. It was recently re-designed to replace its predecessor and the author chaired the production of this course. This course has a dual purpose of supporting students with communication needs in management education and in the workplace. The predecessor course (pre-UBCCE henceforth) was primarily book-based (six books) with online only tutorials. It had a relatively low student satisfaction rate compared to other language courses due to the amount, nature and organisation of the content, and its heavy focus on academic study. Additionally, it had issues with its assessment strategy. Despite all this, students 
progressed well and it continued to recruit a high number of students (circa 700 each year on average for 10 years). A successor course was needed which meant understanding student needs in OUBS as much as possible. This led to adopting an evidence-based approach to the course design, thus necessitating student needs analysis which is an essential aspect of course design in the field of ESP (e.g., Bargiela-Chiappini et al., 2007; Basturkmen, 2012). An evidence-based approach to the course design requires gathering evidence for course content, the nature of teaching and learning, assessment and the delivery of the course in relation to student needs both in their academic studies and professional contexts. For this evidence-based approach, multiple data collection methods were needed as explained below. All data was collected following institutional ethical guidelines.

\subsection{Data collection}

\subsubsection{Student surveys}

A total of 477 students studying pre-UBCCE were invited to participate in a survey to understand their needs which could inform the design of UBCCE. Eighty-one (52 female; 29 male) students responded to the survey, with 26 responding to some of the survey questions partially. The survey focused on course materials format (printed book, online, audio-video), type of activities, use of multimodal resources, listening and speaking, types of business case studies and assessment strategy. This paper also draws on the end of course evaluation student satisfaction survey 2019 data and mid-course survey (both anonymous) based on the new course (i.e., UBCCE). Seventy-six of the 687 students invited to the course evaluation survey responded and 232 responses were received for the mid-course evaluation survey. The surveys aimed to understand self-reported student experiences regarding student satisfaction with the quality of module material, workload, student interactions, tutorials, understanding of module content, tutor assessment feedback and development of professional or work related skills. While the pre-UBCCE student survey data provided information about what students needed and wanted in the new course, the UBCCE course evaluation data offered some insights into whether the new course addressed these needs.

\subsubsection{Content analysis of undergraduate business courses}

In order to understand students' academic business communication needs, a high level content analysis of first year and second year compulsory business management courses (one per year) was conducted for the topics and key business 
management concepts and frameworks. In addition, course assignments were collected for a genre analysis (e.g., see Bhatia, 2008; Coffin \& Donohue, 2014) to find out the type of genres students are expected to produce.

\subsubsection{Student online forum discussions}

Three online forum discussions were organised to gather further information about student needs and their views about what the new course (i.e., UBCCE) should look like. The pre-UBCCE students participated in these online discussions. The following three questions were posted to the online forum inviting students to respond to them: 1) How much study material do you prefer to be printed and online? 2) What is your view about real-time online tutorials? 3) What three specific changes would you make to the current course (i.e., pre-UBCCE)? There were 50, 55 and 35 online forum posts respectively made to these questions by different students. There were 15,453 words in total.

\subsubsection{Industry insights}

The UK Higher Education Quality Assurance Agency (QAA) subject benchmark statement for business and management highlights communication skills and other "soft" or "generic" skills such as teamworking as essential graduate attributes (e.g., see QAA, 2019). In addition to this QAA benchmark, it was necessary to understand what other graduate employability skills various industries want in their employees because employability is central to any university programmes for their success as emphasised in the literature (e.g., Jackson, 2014; Ortiz, Region-Sebest, \& MacDermott, 2016). Therefore, in line with the OU's student employability agenda, industry insights for employability skills were examined by looking through authentic education and skills survey reports. For this, two reports by the Confederation of British Industries (CBI) were considered: CBI (2012, 2015). CBI is an influential organisation in the UK business world and represents the voice of UK businesses. Thus, their reports were considered authentic and relevant for the course design.

\subsubsection{Consultations with business management academics}

As with pre-UBCCE, the new course design involved consultations with the Director of Teaching for the undergraduate programmes and business lecturers from OUBS to decide on the content of the course. The consultation took the form of a series of meetings and email exchanges and critical reading of course syllabus and materials by business lecturers. 


\subsection{Data analysis}

The data was analysed in different ways, depending on the data type. The data from the surveys (pre-UBCCE student survey and UBCCE evaluation) were analysed using descriptive statistics to examine frequencies and central tendencies following Roever and Phakiti (2018).

Two OUBS undergraduate courses were scanned for the topics covered in business management and the type of teaching/leaning activities which could be reflected in UBCCE. Importantly, an SFL-based analysis of the assignment task briefs in the two modules examined was conducted to identify prompted genre types. The analysis provides information about the kind of texts (spoken or written) students are expected to produce in their studies and the kind of language resources they need to succeed in producing them. Genre analysis is a common practice in ESP (see Section 2.2), and academic and professional writing research and pedagogy (e.g., Bhatia \& Bremner, 2014; Coffin \& Donohue, 2014; Nesi \& Gardner, 2012; Ravelli, 2004). The genre analysis approach was informed by Halliday's Systemic Functional Linguistics (SFL), especially the works of Martin and Rose (2007) and Rose and Martin (2012). The SFL view of genre provides information about the social context of language use and the lexicogrammatical resources used to construe the intended meaning making as discussed in Section 2.2. Each genre such as arguing follows stages to achieve its goal. For example, exposition as an arguing genre which argues for a point has these stages: Thesis ${ }^{\wedge}$ Argument $^{\wedge}$ Reiteration. The analysis of assignment briefs for prompted genres provides insights into the type of writing texts business students are expected to produce in business management (for more details, see Shrestha, 2020).

The forum posts and the open comments in the surveys were thematically analysed broadly following Braun and Clarke (2006). Themes were identified based on their "keyness" in relation to the research questions rather than their frequency. This means a deductive method (top down) was used for this purpose to understand students' needs based on their experiences.

\section{Results}

\subsection{Student needs analysis}

\subsubsection{Course content}

Pre-UBCCE focused on academic literacy needed for business studies and did not include any learning materials for oral business communication. It included 
business case studies on multinational companies like Nike and Walmart. The preUBCCE student needs survey asked students three questions about these aspects for UBCCE. The results showed that out of 61 respondents, 54\% (33) replied "yes" to "Would you have liked to enhance your oral business communication skills?". The other question was "How motivating are the case studies in pre-UBCCE?" To this question, out of 56 responses, 61\% (34) stated "motivating”, 27\% (15) "neither motivating nor unmotivating" and 12\% (7) "unmotivating". The third question asked 'What kind of case studies do you prefer?' to which the responses were "large multinational companies" 7\% (4), "UK-based companies” 18\% (10), "small and medium companies" 7\% (4), "non-UK” 2\% (1) and "a mix of all” $66 \%$ (37).

The course content was also determined by closely consulting the OUBS business lecturers. They were invited to contribute to the syllabus design through joining course team meetings and commenting on the syllabus documents to begin with. Then, they provided feedback on all teaching, learning and assessment materials. They emphasised the importance of both oral and written business communication for their students and a wider variety of case studies, thus confirming the pre-UBCCE student survey. In addition, they suggested focusing on both academic and workplace communication including aspects such as team working and workplace learning.

The course content was additionally informed by QAA's subject benchmark statement for business and management (QAA, 2019). Particularly relevant attributes were employability, communications including the use of digital tools, ability to work collaboratively with others, problem-solving and self-reflection. These attributes were confirmed as important by industry insights as revealed by the CBI survey reports 2012 and 2015. For example, the 2015 CBI report, based on responses from $300 \mathrm{UK}$ organisations, stated that employers were concerned about their employees' English literacy skills (over 40\%) and team working (33\%) as a result of which they had to offer them "remedial training". Importantly, about half of the surveyed employers in the CBI report were not satisfied with their employees' communication skills (whether written or oral). The report also recommended that "universities can look to do more to help them prepare for the transition into work" (CBI, 2015, p. 54). All these insights from the reports were taken into consideration while designing this course.

In order to further gather evidence to make the course responsive to student needs, two OUBS compulsory courses were scanned. The scan helped to identify the key topics, concepts and theoretical frameworks or models taught in the first year and the second year. This information was essential for understanding the 
academic context. Among the identified aspects in the course, the following were chosen as key to UBCCE:

1) Key frameworks - SWOT, ${ }^{1}$ STEEP, theories of globalisation, stakeholder model, reflective thinking frameworks by Kolb (1984) and Gibbs (1988).

2) Key concepts and topics - business environment, globalisation, business ethics and corporate social responsibility, team working, negotiation, business argument, basic financial concepts (e.g., types of accounts); key aspects of marketing; selection and recruitment, workplace learning and self-reflection.

3) Business case studies - a wide range of case studies representing large, medium and small organisations including charities (e.g., Tesco, Cafédirect, Fitch).

Additionally and importantly, an SFL-informed analysis of assignment tasks on the same courses for prompted genres was carried out. Table 1 provides a summary of the genre analysis of the assignment in the first year course. It shows that case study analysis is a key genre in which students are expected to analyse the contextualised information (case study) to produce abstract and decontextualized analysis drawing on course concepts and make business context-relevant recommendations. Furthermore, assignment briefs in an OUBS level 2 compulsory course were analysed in a similar way which revealed similar prompted genres in assignments. The key genres were case study analysis and essay, thus indicating these two genres being prominent. As students encounter these two genres in OUBS courses, these genres were taught in detail in the UBCCE (see Table 2).

A summary of study materials developed for one block out of three in light of the above results is presented in Table 2. The course is divided into three blocks and as shown in the table, each session (equivalent to one week study [9-10 h]) has both business management and language and literacy foci. The other two blocks were: Block 2 Persuading and Block 2 Collaborating. While Block 2 focuses on persuasive business communication and associated language resources (e.g., negotiation, business ethics discussion, presentations), Block 3 is about collaborative business communication including teamworking and virtual communication.

\footnotetext{
1 SWOT is short for Strengths, Weaknesses, Opportunities and Threats. It is a common analytical tool used to evaluate the external and the internal business environments of an organisation. STEEP is short for Social, Technological, Economic, Environmental and Political factors. It is a common framework used to analyse an organisation's external environment.
} 


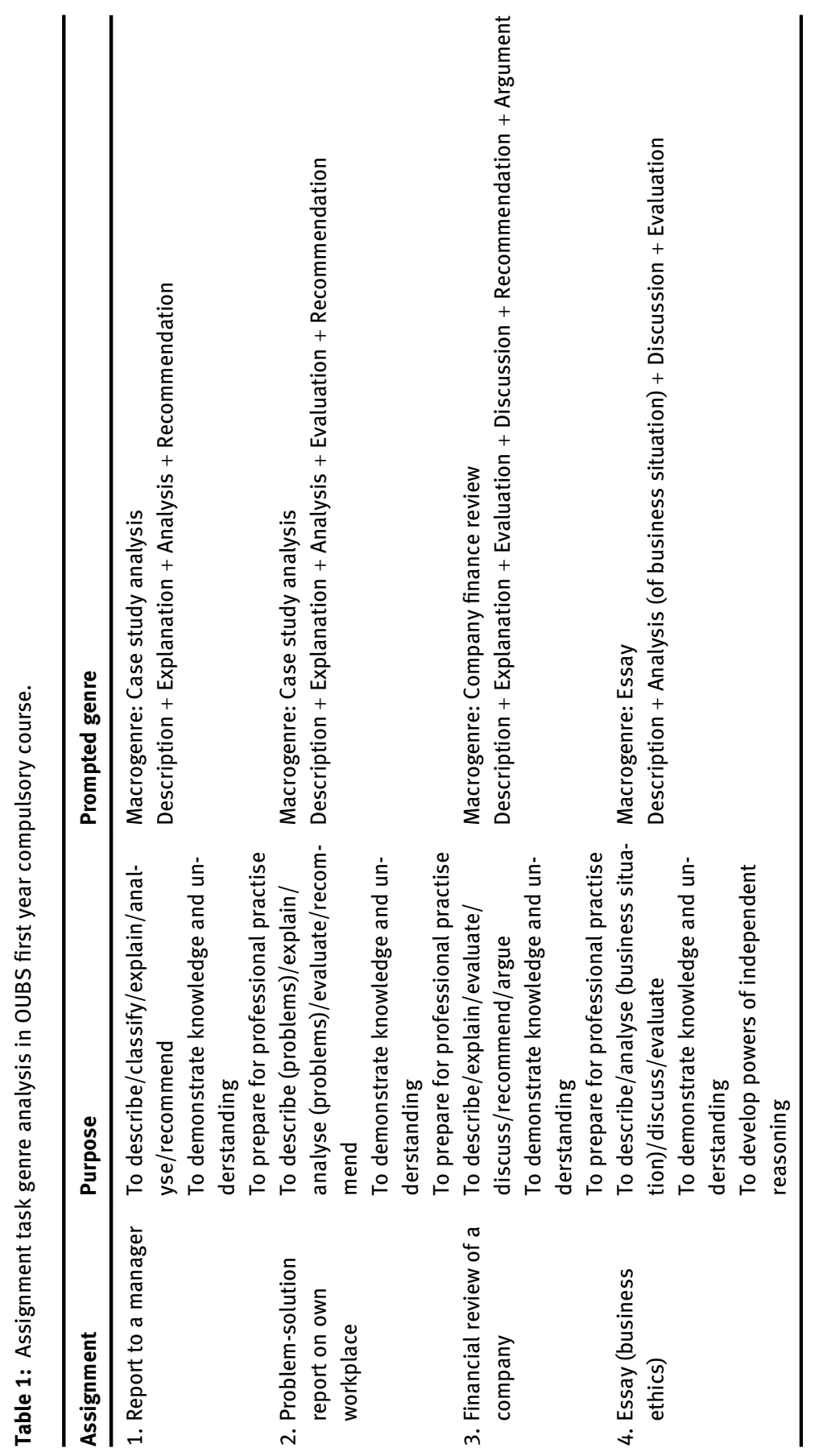


Table 2: Block 1 analysing.

\begin{tabular}{|c|c|c|}
\hline Session title & Business and management & $\begin{array}{l}\text { Language and literacy (including } \\
\text { lexicogrammar) }\end{array}$ \\
\hline $\begin{array}{l}\text { Your communication } \\
\text { skills }\end{array}$ & $\begin{array}{l}\text { Audit own business communi- } \\
\text { cation skills }\end{array}$ & $\begin{array}{l}\text { Role of language in business commu- } \\
\text { nication: audience, purpose and } \\
\text { context (applicable to all sessions) }\end{array}$ \\
\hline $\begin{array}{l}\text { Communicating the } \\
\text { main point }\end{array}$ & $\begin{array}{l}\text { Gist of business communica- } \\
\text { tion; key points } \\
\text { Case studies }\end{array}$ & $\begin{array}{l}\text { Reading for key points; nominalisa- } \\
\text { tion; noun phrases }\end{array}$ \\
\hline $\begin{array}{l}\text { Summarising and giving } \\
\text { presentations }\end{array}$ & $\begin{array}{l}\text { Summary of a business case } \\
\text { study; presentation slides; } \\
\text { digital tools }\end{array}$ & $\begin{array}{l}\text { Summarising; nominalisation; noun } \\
\text { phrases; audience and context }\end{array}$ \\
\hline $\begin{array}{l}\text { Analysing business } \\
\text { case studies: SWOT }\end{array}$ & $\begin{array}{l}\text { SWOT framework and analysis; } \\
\text { case studies (Café Direct) }\end{array}$ & $\begin{array}{l}\text { Reading and selecting relevant infor- } \\
\text { mation } \\
\text { Case study analysis genre; framing a } \\
\text { case study analysis }\end{array}$ \\
\hline $\begin{array}{l}\text { Analysing business } \\
\text { case studies: STEEPLE }\end{array}$ & $\begin{array}{l}\text { STEEPLE framework and anal- } \\
\text { ysis; case studies (student } \\
\text { written texts) }\end{array}$ & $\begin{array}{l}\text { Reading and selecting relevant infor- } \\
\text { mation } \\
\text { Case study analysis genre; framing a } \\
\text { case study analysis }\end{array}$ \\
\hline $\begin{array}{l}\text { Giving a presentation } \\
\text { and reflecting }\end{array}$ & $\begin{array}{l}\text { Business presentation; reflec- } \\
\text { tive framework: Kolb's reflec- } \\
\text { tive cycle }\end{array}$ & $\begin{array}{l}\text { Reflecting on own business commu- } \\
\text { nication } \\
\text { Application of Kolb's framework using } \\
\text { language of personal reflection }\end{array}$ \\
\hline $\begin{array}{l}\text { Analysing problems and } \\
\text { proposing solutions }\end{array}$ & $\begin{array}{l}\text { Business problems and solu- } \\
\text { tions } \\
\text { Case studies }\end{array}$ & $\begin{array}{l}\text { Problem-solution genre; } \\
\text { Describing and analysing problems; } \\
\text { language of proposing solutions } \\
\text { (including hedging and boosting) }\end{array}$ \\
\hline $\begin{array}{l}\text { Writing up your results } \\
\text { using evidence }\end{array}$ & $\begin{array}{l}\text { Business analysis results } \\
\text { Mini case studies }\end{array}$ & $\begin{array}{l}\text { Referencing (continued through the } \\
\text { course); language of reporting }\end{array}$ \\
\hline
\end{tabular}

\subsubsection{Course format}

It is worth noting that the pre-UBCCE was criticised by students for having too many books. In light of this criticism, it was essential to strike a balance between printed, audio-video and online materials. To identify potential student needs in this respect, the survey asked a few questions about the format of the pre-UBCCE and what they preferred.

In response to "You are studying pre-UBCCE with books and integrated online activities. There is a possibility to make UBCCE less book-based and more onlinebased. Which format do you prefer?", the participating students responded: existing format (59\%), more online but one book (34\%) and no preference (5\%). They were then asked "How easy to use did you find the existing pre-UBCCE 
material format?” and the responses were: very easy (13\%), easy (31\%), neither easy nor difficult (33\%), difficult (22\%) and very difficult (1\%). The next question was "How useful did you find the pre-UBCCE material format?" to which the respondents made these choices: very useful (26\%), useful (47\%), neither useful nor useless (22\%), useless (3\%) and very useless (3\%). There was a question about online activities: “How useful did you find the online activities?”. The responses were very useful (21\%), useful (33\%), neither useful nor useless (24\%), useless $(17 \%)$ and very useless (5\%). Finally, they were asked "To study in general, which do/would you prefer?”. Figure 1 shows the result for this question in which 1 is the most preferred option and 4 the least preferred. As the figure shows, the students still wanted printed books (66\%) although a large majority $(76 \%)$ preferred a combination of printed and online materials.
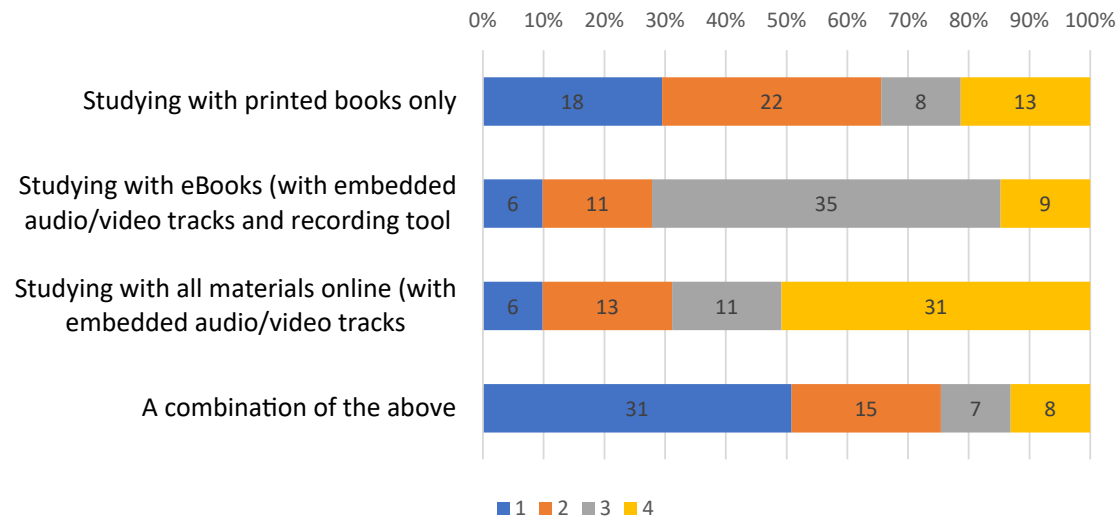

Figure 1: Preference for the format of the study materials.

The survey data was supported by the forum post data. While a number of forum posts suggested continuing with printed books, many also indicated the need for more online presence of the course. The quotes below illustrate the student preferences for print and online in response to the question "How much study material do you prefer to be printed and online?":

I find the good old text books the best format for learning, you can smell them, scribble on them and draw lines and arrows until your heart is content. The live online I have experienced for the first time on this module and must admit I was impressed with the connection and interaction. (Forum post 2)

I know how difficult it is for you when you have to keep skipping through the books by reading the individual sessions then referring to the resource book then back to the answers at 
the back of the session books. I also find it difficult as I have paralysis in both of my hands although I do have a non medical helper courtesy of the OU. I personally prefer the OU online sessions as a disabled student. (Forum post 5)

I find online and PDF formats more useful. I personally prefer this. I do travel frequently and carrying books or printed materials are not practical. Having these on your IPAD is very convenient when you are mobile. (Forum post 13)

The following forum post sums up the majority of the forum posts:

I understand the need for both online and printed material.

Depending on what can be done to make the printed version run more logically I would be pushing for more material online to compliment this.

I agree with the "scribbling”, "touch and feel" commentary regarding the books, however with an appropriate guide this can be done online and saved with any annotations made.

In conclusion for me it's a blend of both but an increased percentage online. (Forum post 35)

Given that the course is offered globally and increasingly younger students under the age of 30, unlike traditional mature OU students, are studying OUBS courses (including pre-UBCCE), there was an impetus for an online orientation to the new course. The younger age of the student population in the pre-UBCCE (e.g., $51.3 \%$ of 774 pre-UBCCE students in 2015 aged between 17 and 30) also indicated a preference for online learning due to their use of smart devices such as tablets in daily lives.

The format of the UBCCE was also informed by the OUBS level 1 compulsory course. As the majority of the students come from this course to the UBCCE, it was important to offer similar experience to the students in order to minimise the information load. The OUBS course was primarily online-based with seven printed books for readings. All the teaching and learning activities including audio and video materials were online. This means a blend of both online and print materials. Based on this OUBS course format and the pre-UBCCE student preferences (survey and forum post data), the UBCCE was designed to be primarily online-based with two printed books which replicated part of the online materials. The printed books included case studies, examples of case study analysis texts written by students, theoretical models and frameworks, useful tips on business communication, glossary and audio-video transcripts. The hub of teaching/learning in the course is the course website which contains the course calendar and links to all the learning resources. A summary of the types of learning resources used in the course is presented in Figure $2 .^{2}$

2 A taster unit of UBCCE can be found at - https://www.open.edu/openlearn/money-business/ business-communication-writing-swot-analysis/content-section-0?intro=1. 


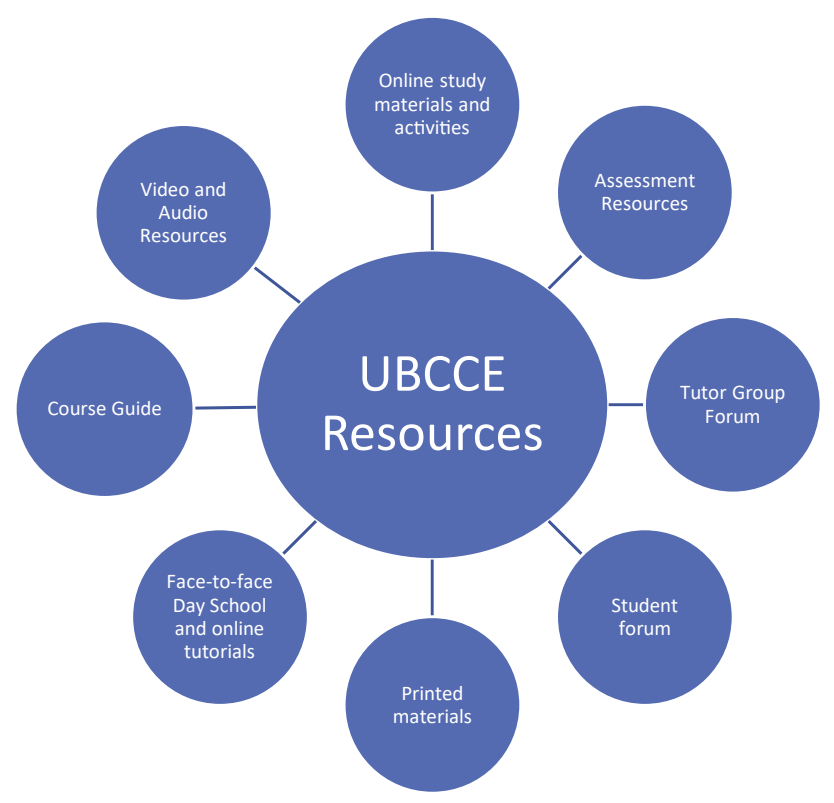

Figure 2: Types of resources in UBCCE.

\subsubsection{Learning and teaching: delivery}

In distance education, the delivery of teaching a course is different from the faceto-face context (Chetwynd \& Dobbyn, 2011). As in all OU courses, UBCCE is selfcontained and students do not have to search for new learning materials except when asked to do so in an activity. The tuition support in the course was informed by the student survey, forum post discussion and the approach adopted by the OUBS Level 1 compulsory course.

The survey asked questions about tutorials. In response to the usefulness of the online tutorials, $85 \%$ of the respondents $(n=33)$ who attended live tutorials reported them being useful. There were respondents who had not attended the live tutorials but their recordings. Among those who watched/listened to these recorded tutorials, $90 \%$ of them $(n=10)$ found the recordings useful.

The online forum posts provided further data on tutorials. The following forum posts summarise the views expressed by the participants:

Personally, I do prefer face to face tutorials, but that's just me. I feel like I learn more and can take things in easier. However, after attending my first online tutorial the other week, I was amazed by how easy and fun it actually was! To be able to sit hundreds of miles away from people, but chat/discuss the same things, and being able to do activities together on the slides is clever and useful! (Forum post 14) 
I find the live online tutorials very useful. You get to interact with your tutor and fellow students without having to leave your house. Once you have downloaded Java and done the necessary testing of the system before the start of the session then things flow easily afterwards. The icons are very easy to use. You have the option of using a mic or type your questions if you are shy. Having the session recorded is very beneficial. Just in case you have missed an important point during the live session or if you did not attend. You have the opportunity of listening to the recordings at your chosen time. You do not have this opportunity with face to face tutorials. (Forum post 16)

I have attended almost all the online tutorials. I really prefer this method especially with my work I cannot always travel. I had a chance to ask many questions, received clarity about some points in the module, helps for the assignment. So I am happy with the online tutorials. Online tutorials with my group were interactive. (Forum post 51)

As these posts indicate, most forum posts suggested that most students preferred online tutorials (live or recorded) due to the flexibility provided by their onlineness. However, some students still wanted to have some face-to-face tutorials.

The decision on the type of tutorials was further informed by the OUBS level 1 compulsory course. It had both face-to-face and online tutorials which students seemed to have liked. Therefore, in light of the pre-UBCCE student preference and the approach taken by the OUBS course, the UBCCE course team decided to hold six 90-min live online tutorials per tutor group (i.e., two tutorials per Block) and their recordings, and one $4 \mathrm{~h}$ face-to-face day school or online alternative in Block 1.

\subsubsection{Assessment strategy}

An effective assessment strategy is integral to the successful design of a course. It helps to demonstrate its students' achievements during the course. Assessment is also a tool that tracks students' learning and development. However, it should meet target students' needs in studies and at work (employability). For this purpose, UBCCE drew on OUBS course assignment genre analysis, the student survey and my own unpublished previous study on assessment (Shrestha, 2013).

Given that UBCCE students are primarily from OUBS, it was pertinent to understand the nature of OUBS course assignment genres. As noted in Section 5.1.1 (Table 1), an SFL-based genre analysis of assignment briefs in two OUBS business management compulsory courses was conducted. Table 1 presented the genres expected in the first year OUBS compulsory course. The genres prompted in the second year compulsory course are presented in Table 3 (see Shrestha, 2020 for a detailed discussion). 


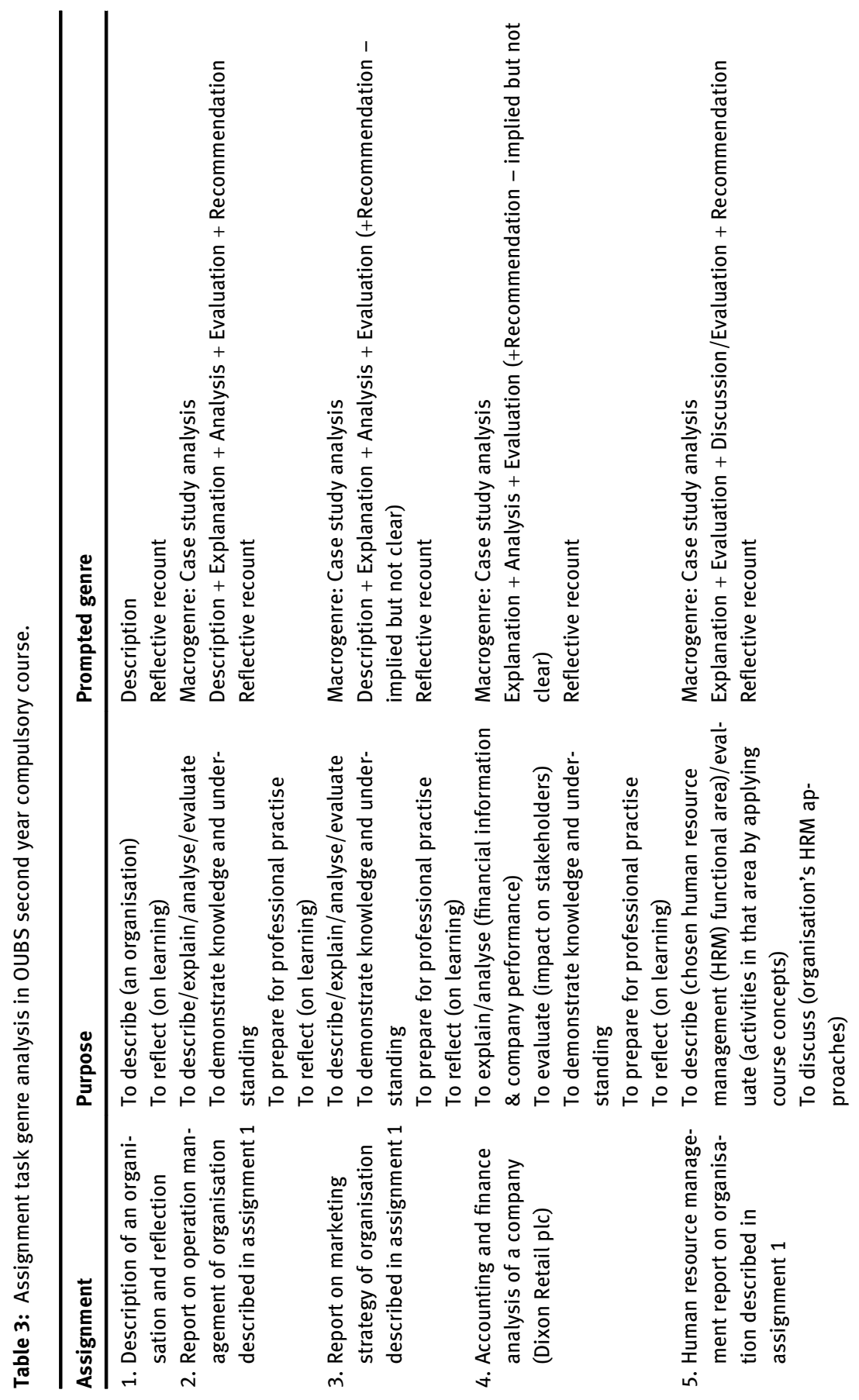




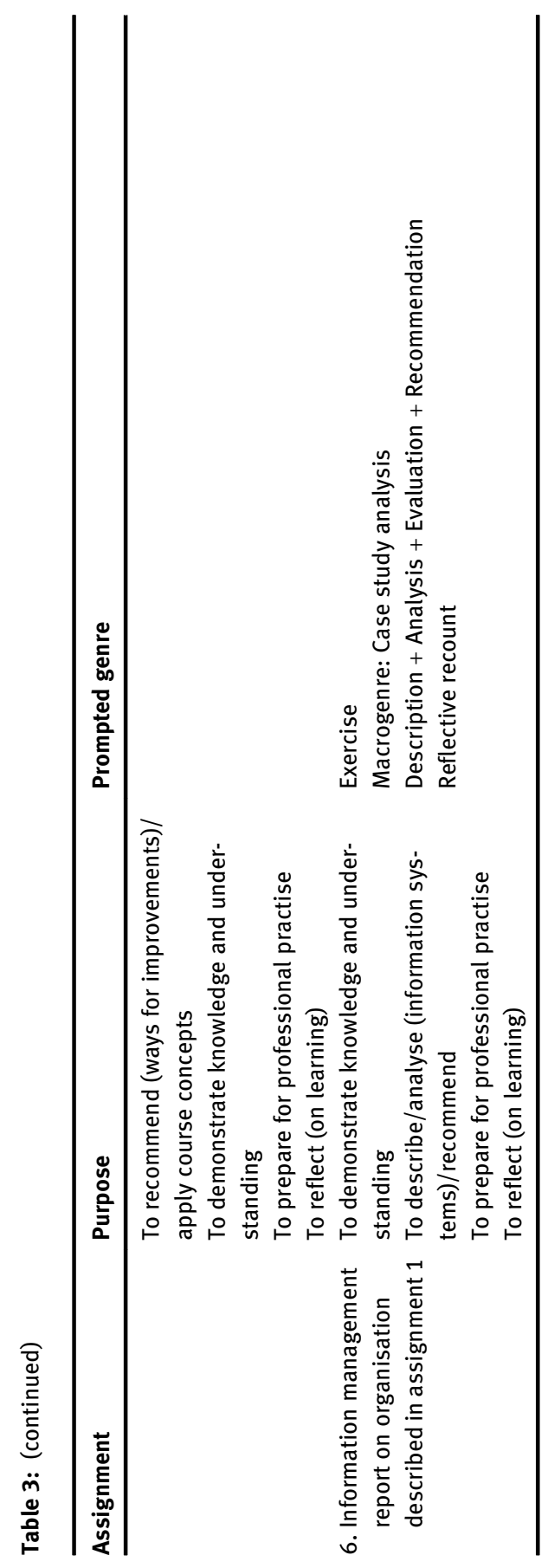


These genre analyses indicated that students in OUBS were predominantly expected to produce case study analysis, essay (arguing/discussing) and reflection genres in their assignments. The focus was on written business communication and thus the OUBS courses lacked oral business communication although it is expected that business graduates master this.

The pre-UBCCE student survey and my previous unpublished study (Shrestha, 2013) examined two aspects of assessment: formative assessment and tutor feedback in pre-UBCCE. Both are essential for promoting students' life-long learning and therefore, they were integral to the design of UBCCE assignments. Pre-UBCCE had the second assignment built on the first one, meaning students wrote both the assignments based on the same case study (reading material) although students wrote a summary of the case study for Assignment 1 and a SWOT case study analysis for Assignment 2. The purpose of doing so was to support students with writing Assignment 2 by making Assignment 1 developmental through the tutor feedback on it. The survey data showed that $91 \%$ of 56 students reported this assessment design being helpful. However, my other study (Shrestha, 2013) showed that requiring students to write a summary in Assignment 1 and then a SWOT analysis in Assignment 2 was not helpful due to the differing genre and lexicogrammatical demands of the two assignments. The tutor feedback was also not found directly relevant to Assignment 2. Pre-UBCCE had Assignment 3 which allowed students to receive some feedback on a draft they voluntarily submitted by email. The survey data indicated that $55 \%$ of 56 students reported to have used this opportunity and among these students, 90\% reported the tutor feedback being useful.

Keeping in view of this empirical evidence, the UBCCE team adopted the assessment strategy presented in Table 4. As it shows, instead of a summary in Assignment 1, students are asked to produce notes (bullet points) on slides which will then feed into Assignment 2 when students write it as both assignments are based on the same case study and the notes from Assignment 1 help them to write a SWOT analysis. Importantly, UBCCE has an oral assignment (Assignment 3) integrated with an online forum discussion. To promote formative feedback and student learning and engagement, students have two opportunities to receive formative feedback on: Assignments 3 and 4. Reflective writing is another key feature of UBCCE in which students are asked to apply a reflective framework such as Gibbs (1988) which also prepares them for their professional context (workplace learning). 
Table 4: Assessment strategy in UBCCE.

2. SWOT case study analysis of case study in $1+$ reflection;

3. Online forum discussion + recorded oral presentation (both

business ethics based on a given case study); formative feedback opportunity

4. Business essay (based on a given case study) + reflection

$40 \%(80 \%+20 \%)$ ( $30 \%$ threshold); formative feedback opportunity

\subsection{Student experiences of the new online course}

As a new online course, we constantly strive to improve it through regular student feedback. The feedback also shows how much it has achieved its objective of meeting business communication needs of distance education students. The student experience of the new course was gathered through two student surveys: one course end evaluation in 2019 and another mid-course evaluation in 2020. The course end survey focused on various aspects of the module and the student satisfaction rate. In total, 76 students responded to the 2019 survey and their satisfaction rate is provided in Table 5.

Table 5: Student course satisfaction rate 2019.

\section{Statements}

I was satisfied with quality of course

Course materials helped maintain my interest

Workload fitted with personal circumstances

Course structure enabled interaction with peers

I was satisfied with opportunities to attend tutorials

There were sufficient opportunities to check understanding

Instructions on completing assessment were easy to follow

It was obvious how module materials related to assessment

There was sufficient time to prepare for final assignment

I was satisfied with support from tutor

I received sufficient advice and guidance in relation to module

I recommend OU study to other students
Satisfaction rate \% 
As can be seen in Table 5, students were highly satisfied with most aspects of the course. Only interaction with peers was rated low which is not surprising in distance education due to the independent nature of distance learners.

The survey data was supplemented by some open comments. The anonymous comments below reflect the positive impact on student needs and thus indicate the potential success of the course:

\begin{abstract}
This course has given me a range of skills that will last a lifetime and would most certainly have helped me at the outset of my studies with the OU. This module gives you the framework and tools on how to communicate successfully in an academic arena and with work-based situations. I would suggest this is used as part of any foundation or core modules to any qualification with the OU.
\end{abstract}

I work as a quality and compliance manager - since I started this module I feel more confident when communicating to others.

I enjoyed every bit of this module and will recommend it to anyone who has a very tight schedule in their daily activities as employees or entrepreneurs. Thanks so much to the OU team for such a fantastic learning program.

The mid-course survey took place approximately halfway through the course. Specifically, it asked students questions about the effect of Assignment 1 on Assignment 2 writing, online tutorial experience, and support with writing assignments in other modules as a result of studying UBCCE. In total, there were 232 responses. In response to "Assignment 1 was designed to help you prepare for Assignment 2. Did writing Assignment 1 and receiving tutor feedback on it help you with Assignment 2?", 87\% responded "yes". When asked "What has been your experience of online tutorials so far?”, 65\% indicated that they are very useful for writing assignments while $28 \%$ did not attend for personal reasons or due to work schedule. Finally, they were asked "Has this course supported you with writing assignments in other courses you are studying?”. In their answer, 68\% responded positively.

\title{
6 Discussion
}

Designing a successful business communication course in English involves a complex process. This paper presented the process of doing so by drawing on a number of sources and methods driven by student needs. The student needs became the key factor to support the evidence-based approach taken to design this UBCCE, as reported in the wider ESP literature (Flowerdew, 2013). The paper addressed UBCCE student needs through two research questions: What are 
distance undergraduate business management students' communication needs? In what ways does an evidence-based course design address such needs?

The first research question was addressed by conducting the student needs analysis. The analysis was through mainly student surveys, forum discussions, business academic consultations and an analysis of business management course contexts which helped to determine the type of content for BCCE and meet student needs. Particularly, it needs to be emphasised that identifying student needs based on employed students' experiences in their workplace through multiple methods is powerful. For example, the choice and range of case studies and the inclusion of oral business communication in the course were based on the student preference drawing on their professional experiences. This is in line with the literature which suggests incorporating both students' individual needs and what they encounter in the target business communication context into the course (Bargiela-Chiappini \& Zhang, 2013; Cavanagh et al., 2019; Flowerdew, 2013). The needs analysis also suggested including content on specific aspects of business communication such as negotiation and teamworking in the new course as highlighted in recent studies (Bhatia \& Bremner, 2014; Moshiri \& Cardon, 2020). Additionally, the course design drew on business discourse studies for authentic business communication (Koester, 2010). Another key finding was the effective use of an SFL-based genre analysis to inform the course design (Coffin \& Donohue, 2014). It was found that case study analysis and essay were key written assignment genres in OUBS courses as in the wider literature (Nesi \& Gardner, 2012). The choice of content was also driven by the industry insight reports provided by professional organisations such as CBI which is atypical in business communication course design.

The second research question was dependent on the findings of the first one. Based on the needs analysis, the UBCCE adopted a mix of online primarily and print-based materials. The tutorials were online with an additional face-to-face day school. It is similar to what Knight (2017) reports on blended mobile learning in other BCCE contexts although they were not distance learning per se. In fact, there is no study of this kind completely based on distance learning.

Like the course content, assessment design was also driven by the findings from student needs analysis. In particular, the SFL-based genre analysis of the written assignment task briefs in two OUBS compulsory courses was instrumental as it provided solid evidence for the choice of assignment tasks, following Douglas (2013). The genre analysis also indicated a significant gap in OUBS assessment, oral business communication, as in some other contexts (Clokie \& Fourie, 2016). It is worth noting that although the new UBCCE included oral assessment, it was unable to include interactive oral business communication assessment and was 
thus limited to oral presentations due to the technical difficulty of managing a significantly large number (e.g., over 500) of small group interactions online. This is something that needs to be considered for the future.

Overall, as shown by the course evaluation surveys, the student needs analysis consisting of multiple methods served as a powerful tool for designing an effective online BCCE which, to the author's knowledge, has not been reported in the literature. By being an evidence-based course, UBCCE has been a very successful and popular online business communication course at the University, recruiting a large number of students (over 1,300 students each year). In fact, it received a Faculty Teaching Excellence Award as judged by students in 2018 and it was a Finalist in the British Council's ELTons Innovation Award 2019 in the category Excellence in Course Innovation. ${ }^{3}$

\section{Conclusion}

This paper reported on the design of an online UBCCE for distance learners with the aim to identify their business communication needs and the extent of meeting those needs via UBCCE. This study is probably the first of its kind reported in the literature, particularly as it drew on students who were already working and thus provided more insightful data. It examined how an evidencebased approach driven by student needs analysis enabled the course team to design an online UBCCE at The OU in order to meet distance learner needs. The paper argued that an evidence-based approach truly driven by student needs analysis methods which involve student surveys, genre analysis, business discourse study, industry insights and consultations with business academics can lead to designing a successful online BCCE. This paper provides examples of needs analysis methods to English business communication course teachers and researchers not only in distance education but also in traditional university contexts. As the business world and higher education are grappling with challenges of the pandemic (COVID-19) (Gacs, Goertler, \& Spasova, 2020), this paper shows how an online business communication course could be designed as a solution.

Despite the use of a wide range of student needs analysis methods, this study has some limitations too. First, the data comes from students of one university and thus may limit the generalisability of the findings. Second, the survey response rates were relatively low despite the large number of students studying the course which potentially limits the significance of the survey data. Third, although the

3 See https://www.teachingenglish.org.uk/article/eltons-finalists-2019. 
student needs analysis data emphasised the importance of interactive oral business communication, the course failed to integrate interactive oral assessment into the assessment design owing to technical difficulties of managing a large number of group interactions online. Fourth, conducting the level of student needs analysis reported in this paper might not be possible in other contexts due to time and resource constraints though not unachievable. Finally, the needs analysis process did not include the first hand data from target business communication contexts but relied on secondary sources such as business discourse studies (e.g., Koester, 2010). Future studies should address these limitations and challenges of online business communication given most businesses are likely to be continued online as a result of the global pandemic. Additionally and importantly, future studies should examine the transfer of aspects of business communication courses like this one to business studies contexts and workplace or professional settings which is lacking (Shrestha, 2017).

Acknowledgments: I am grateful to my colleagues, Dr Ursula Stickler and Professor Agnes Kukulska-Hulme for their insightful comments on a previous version of this paper. I am also thankful to two anonymous reviewers for their very helpful comments.

\section{References}

Angouri, J. (2018). Culture, discourse, and the workplace. Milton Park, Abingdon, Oxon; New York: Routledge.

Bargiela-Chiappini, F., Nickerson, C., \& Planken, B. C. (2007). Business discourse. Basingstoke: Palgrave Macmillan.

Bargiela-Chiappini, F., \& Zhang, Z. (2013). Business English. In B. Paltridge, \& S. Starfield (Eds.), The handbook of English for specific purposes (pp. 193-211). Malden, MA: John Wiley \& Sons.

Basturkmen, H. (2010). Developing courses in English for specific purposes. Basingstoke: Palgrave Macmillan.

Basturkmen, H. (2012). Languages for specific purposes curriculum creation and implementation in Australasia and Europe. The Modern Language Journal, 96, 59-70.

Bawarshi, A. S., \& Reiff, M. J. (2010). Genre: An introduction to history, theory, research, and pedagogy. Fort Collins, COL: WAC Clearinghouse.

Benesch, S. (2009). Theorizing and practicing critical English for academic purposes. Journal of English for Academic Purposes, 8(2), 81-85.

Bhatia, V. K. (1993). Analysing gengre: Language use in professional settings. London: Longman. Bhatia, V. K. (2004). Worlds of written discourse. London: Continuum.

Bhatia, V. K. (2008). Genre analysis, ESP and professional practice. English for Specific Purposes, 27(2), 161-174.

Bhatia, V. K., \& Bremner, S. (2012). English for business communication. Language Teaching, 45(4), 410-445. 
Bhatia, V. K., \& Bremner, S. (2014). The Routledge handbook of language and professional communication. New York, NY; Oxon: Routledge.

Braun, V., \& Clarke, V. (2006). Using thematic analysis in psychology. Qualitative Research in Psychology, 3(2), 77-101.

Cavanagh, T. M., Leeds, C., \& Peters, J. M. (2019). Increasing oral communication self-efficacy improves oral communication and general academic performance. Business and Professional Communication Quarterly, 82(4), 440-457.

CBI. (2012). Learning to grow: What employers need from education and skills. London: Confederation of British Industry.

CBI. (2015). Inspiring growth: CBI/Pearson education and skills survey 2015. London: Confederation of British Industry.

Cheng, A. (2007). Transferring generic features and recontextualizing genre awareness: Understanding writing performance in the ESP genre-based literacy framework. English for Specific Purposes, 26(3), 287-307.

Chetwynd, F., \& Dobbyn, C. (2011). Assessment, feedback and marking guides in distance education. Open Learning: The Journal of Open, Distance and e-Learning, 26(1), 67-78.

Clokie, T. L., \& Fourie, E. (2016). Graduate employability and communication competence: Are undergraduates taught relevant skills? Business and Professional Communication Quarterly, 79(4), 442-463.

Coffin, C., \& Donohue, J. P. (2012). Academic Literacies and systemic functional linguistics: How do they relate? Journal of English for Academic Purposes, 11(1), 64-75.

Coffin, C., \& Donohue, J. (2014). A language as social semiotic based approach to teaching and learning in higher education. Malden, MA: John Wiley \& Sons.

Colpaert, J. (2006). Pedagogy-driven design for online language teaching and learning. CALICO Journal, 23(3), 477-497.

Crosling, G., \& Ward, I. (2002). Oral communication: The workplace needs and uses of business graduate employees. English for Specific Purposes, 21(1), 41-57.

Douglas, D. (2013). ESP and assessment. In B. Paltridge, \& S. Starfield (Eds.), The handbook of English for specific purposes (pp. 367-383). Malden, MA: John Wiley \& Sons.

Flowerdew, L. (2013). Needs analysis and curriculum development in ESP. In B. Paltridge, \& S. Starfield (Eds.), The handbook of English for specific purposes (pp. 325-346). Malden, MA: John Wiley \& Sons.

Gacs, A., Goertler, S., \& Spasova, S. (2020). Planned online language education versus crisisprompted online language teaching: Lessons for the future. Foreign Language Annals, 53(2), 380-392.

Gibbons, P. (2002). Scaffolding language, scaffolding learning: Teaching second language learners in the mainstream classroom. Portsmouth, $\mathrm{NH}$ : Heinemann.

Gibbons, P. (2006). Bridging discourses in the ESL classroom: Students, teachers and researchers. London: Continuum.

Gibbs, G. (1988). Learning by doing: A guide to teaching and learning methods. Oxford: Further Education Unit, Oxford Polytechnic.

Halliday, M. A. K. (1993). Towards a language-based theory of learning. Linguistics and Education, 5(2), 93-116.

Halliday, M. A. K. (1994). An introduction to functional grammar (2nd ed.). London: Arnold.

Hampel, R., \& Stickler, U. (2015). Developing online language teaching: Research-based Pedagogies and reflective practices. New York: Palgrave Macmillan. 
Hasan, R. (2005a). The collected works of Ruqaiya Hasan. Vol. 1, Language, society and consciousness. London: Equinox.

Hasan, R. (2005b). Semiotic mediation and three exotropic theories: Vygotsky, Halliday and Bernstein. In J. Webster (Ed.), Language, society and consciousness: The collected works of Ruqaiya Hasan. Vol. 1. London: Equinox.

Hellekjær, G. O., \& Fairway, T. (2015). The mismatch between the unmet need for and supply of occupational English skills: An investigation of higher educated government staff in Norway. Higher Education, 70(6), 1033-1050.

Hyland, K. (2003). Genre-based pedagogies: A social response to process. Journal of Second Language Writing, 12(1), 17-29.

Hyland, K. (2007). Genre pedagogy: Language, literacy and L2 writing instruction. Journal of Second Language Writing, 16(3), 148-164.

Jackson, D. (2014). Business graduate performance in oral communication skills and strategies for improvement. International Journal of Management in Education, 12(1), 22-34.

Johns, A. M. (2008). Genre awareness for the novice academic student: An ongoing quest. Language Teaching, 41(2), 237-252.

Johns, A. M. (2013). The history of English for specific purposes research. In B. Paltridge, \& S. Starfield (Eds.), The Handbook of English for Specific Purposes (pp. 5-30). Malden, MA: John Wiley \& Sons.

Knight, M. (2017). Mobile learning: A proven pedagogy for business and professional communication. Business and Professional Communication Quarterly, 80(2), 135-136.

Koester, A. (2006). Investigating workplace discourse. London: Routledge.

Koester, A. (2010). Workplace discourse. London: Continuum.

Kolb, D. (1984). Experiential learning. Englewood Cliffs, NJ: Prentice-Hall.

Lea, M., \& Street, B. V. (1998). Student writing in higher education: An academic literacies approach. Studies in Higher Education, 23(2), 157-172.

Lillis, T. M. (2001). Student writing: Access, regulation, desire. London: Routledge.

Martin, J. R. (1999). Mentoring semogenesis: A genre-based pedagogy. In F. Christie (Ed.), Pedagogy and the shaping of consciousness: Linguistic and social processes. London and New York: Continuum.

Martin, J. R. (2009). Genre and language learning: A social semiotic perspective. Linguistics and Education, 20(1), 10-21.

Martin, J. R., \& Rose, D. (2007). Working with discourse: Meaning beyond the clause. London: Continuum.

Moshiri, F., \& Cardon, P. (2014). The state of business communication classes: A national survey. Business and Professional Communication Quarterly, 77(3), 312-329.

Moshiri, F., \& Cardon, P. (2020). An updated and expanded nationwide study of business communication courses. Business and Professional Communication Quarterly, 83(4), 469-488.

Neeley, T. (2012). Global business speaks English. Harvard Business Review, 90(5), 116-124.

Nesi, H., \& Gardner, S. (2012). Genres across the disciplines: Student writing in higher education. Cambridge: Cambridge University Press.

Ortiz, L. A., Region-Sebest, M., \& MacDermott, C. (2016). Employer perceptions of oral communication competencies most valued in new hires as a factor in company success. Business and Professional Communication Quarterly, 79(3), 317-330. 
Paltridge, B. (2013). Genre and English for specific purposes. In B. Paltridge, \& S. Starfield (Eds.), The handbook of English for specific purposes (pp. 347-366). Malden, MA: John Wiley \& Sons.

Paltridge, B., \& Starfield, S. (2013). The handbook of English for specific purposes. Malden, MA: John Wiley \& Sons.

QAA. (2019). Subject benchmark statement for business and management (4th ed.). Gloucester: The Quality Assurance Agency for Higher Education.

Ravelli, L. J. (2004). Signalling the organisation of written texts: Hyper-themes in management and history essays. In L. J. Ravelli, \& R. A. Ellis (Eds.), Analysing academic writing: Contextualised frameworks (pp. 104-130). London: Continuum.

Roever, C., \& Phakiti, A. (2018). Quantitative Methods for second language research: A problemsolving approach. New York, NY; Oxon: Routledge.

Rose, D., \& Martin, J. R. (2012). Learning to write, reading to learn: Genre, knowledge and pedagogy in the Sydney school. Sheffield; Bristol, CT: Equinox Publishing Ltd.

Shrestha, P. N. (2013). Formative tutor feedback and student learning: Is there evidence of learning? [Unpublished research report]. Higher Education Academcy.

Shrestha, P. N. (2017). Investigating the learning transfer of genre features and conceptual knowledge from an academic literacy course to business studies: Exploring the potential of dynamic assessment. Journal of English for Academic Purposes, 25, 1-17.

Shrestha, P. N. (2020). Dynamic assessment of students' academic writing: Vygotskian and systemic functional linguistic perspectives. Cham: Springer.

Shrestha, P. N., Fayram, J., \& Demouy, V. (2015). Innovative use of mobile technologies in EAP oral assessment: A pilot study from The Open University. In P. N. Shrestha (Ed.), Current Developments in English for Academic and Specific Purposes: Local innovations and global perspectives (pp. 157-177). Reading: Garnet Education.

Smallwood, M. G. (2020). The need for cross-cultural communication instruction in U.S. business communication courses. Business and Professional Communication Quarterly, 83(2), 133-152.

Swales, J. M. (1990). Genre analysis: English in academic and research settings. Cambridge: Cambridge University Press.

Turner, J. (2011). Language in the academy: Cultural reflexivity and intercultural dynamics. Bristol; Buffalo: Multilingual Matters.

Wardrope, W. J., \& Bayless, M. L. (1999). Content of the business communication course: An analysis of coverage. Business Communication Quarterly, 62(4), 33-40.

White, C. J. (2017). Distance language teaching with technology. In C. A. Chapelle, \& S. Sauro (Eds.), The handbook of technology and second language teaching and learning (pp. 134-148). Oxford: Wiley Blackwell.

Wingate, U. (2018). Academic literacy across the curriculum: Towards a collaborative instructional approach. Language Teaching, 51(3), 349-364.

Woodward-Kron, R. (2005). The role of genre and embedded genres in tertiary students' writing. Prospect, 20(3), 24-41. 


\section{Bionote}

Prithvi N. Shrestha

School of Languages and Applied Linguistics, The Open University, Milton Keynes, UK prithvi.shrestha@open.ac.uk

Prithvi N. Shrestha, an award-winning author (British Council ELTons), is Senior Lecturer in English Language at The Open University, UK. His research interests include academic writing, Systemic Functional Linguistics, sociocultural theory, language assessment and testing, mobile learning and teacher development in developing countries. 